\title{
REVIEW
}

\section{Oral low dose and topical tamoxifen for breast cancer prevention: modern approaches for an old drug}

\author{
Matteo Lazzeronil,*, Davide Serrano', Barbara K Dunn², Brandy M Heckman-Stoddard², Oukseub Lee³, Seema Khan³ \\ and Andrea Decensi ${ }^{1,4}$
}

\begin{abstract}
Tamoxifen is a drug that has been in worldwide use for the treatment of estrogen receptor (ER)-positive breast cancer for over 30 years; it has been used in both the metastatic and adjuvant settings. Tamoxifen's approval for breast cancer risk reduction dates back to 1998, after results from the Breast Cancer Prevention Trial, co-sponsored by the National Cancer Institute and the National Surgical Adjuvant Breast and Bowel Project, showed a 49\% reduction in the incidence of invasive, ER-positive breast cancer in high-risk women. Despite these positive findings, however, the public's attitude toward breast cancer chemoprevention remains ambivalent, and the toxicities associated with tamoxifen, particularly endometrial cancer and thromboembolic events, have hampered the drug's uptake by high-risk women who should benefit from its preventive effects. Among the strategies to overcome such obstacles to preventive tamoxifen, two novel and potentially safer modes of delivery of this agent are discussed in this paper. Low-dose tamoxifen, expected to confer fewer adverse events, is being investigated in both clinical biomarkerbased trials and observational studies. A series of systemic biomarkers (including lipid and insulin-like growth factor levels) and tissue biomarkers (including Ki-67) are known to be favorably affected by conventional tamoxifen dosing and have been shown to be modulated in a direction consistent with a putative anti-cancer effect. These findings suggest possible beneficial clinical preventive effects by low-dose tamoxifen regimens and they are supported by observational studies. An alternative approach is topical administration of active tamoxifen metabolites directly onto the breast, the site where the cancer is to be prevented. Avoidance of systemic administration is expected to reduce the distribution of drug to tissues susceptible to tamoxifen-induced toxicity. Clinical trials of topical tamoxifen with biological endpoints are still ongoing whereas pharmacokinetic studies have already shown that appropriate formulations of drug successfully penetrate the skin to reach breast tissue, where a preventive effect is sought.
\end{abstract}

\section{Introduction}

At present, tamoxifen is the only proven oral agent for the adjuvant hormonal treatment of hormone receptorpositive breast cancer in premenopausal women [1], and it can be used in both pre- and postmenopausal women who are at increased risk of breast cancer [2]. However, the toxicities of tamoxifen, such as thromboembolic events and endometrial cancer, still pose a clinically significant problem overall, especially in the prevention setting. Novel strategies to reduce the adverse side effects

*Correspondence: matteo.lazzeroni@ieo.it

'Divisions of Cancer Prevention and Genetics, European Institute of Oncology, Milan, Italy

Full list of author information is available at the end of the article of tamoxifen, while still retaining its beneficial anticancer properties, are currently being explored. One such strategy for improving the risk/benefit profile of this agent has been to examine the efficacy of lower doses, which are anticipated to be associated with lower toxicity. Another novel preventive strategy that is currently under investigation is the topical application of either tamoxifen or its active metabolites. These two promising alternatives, oral low dose and topical administration of tamoxifen or its active metabolites, are discussed in the present review (Figure 1). Here we present the results of several phase II trials (listed in Table 1), a description of ongoing phase III trials, and future prospects using this approach.

Oral low-dose tamoxifen for breast cancer prevention An overview of the adjuvant tamoxifen clinical trials revealed that the efficacy of $20 \mathrm{mg} /$ day of tamoxifen was 


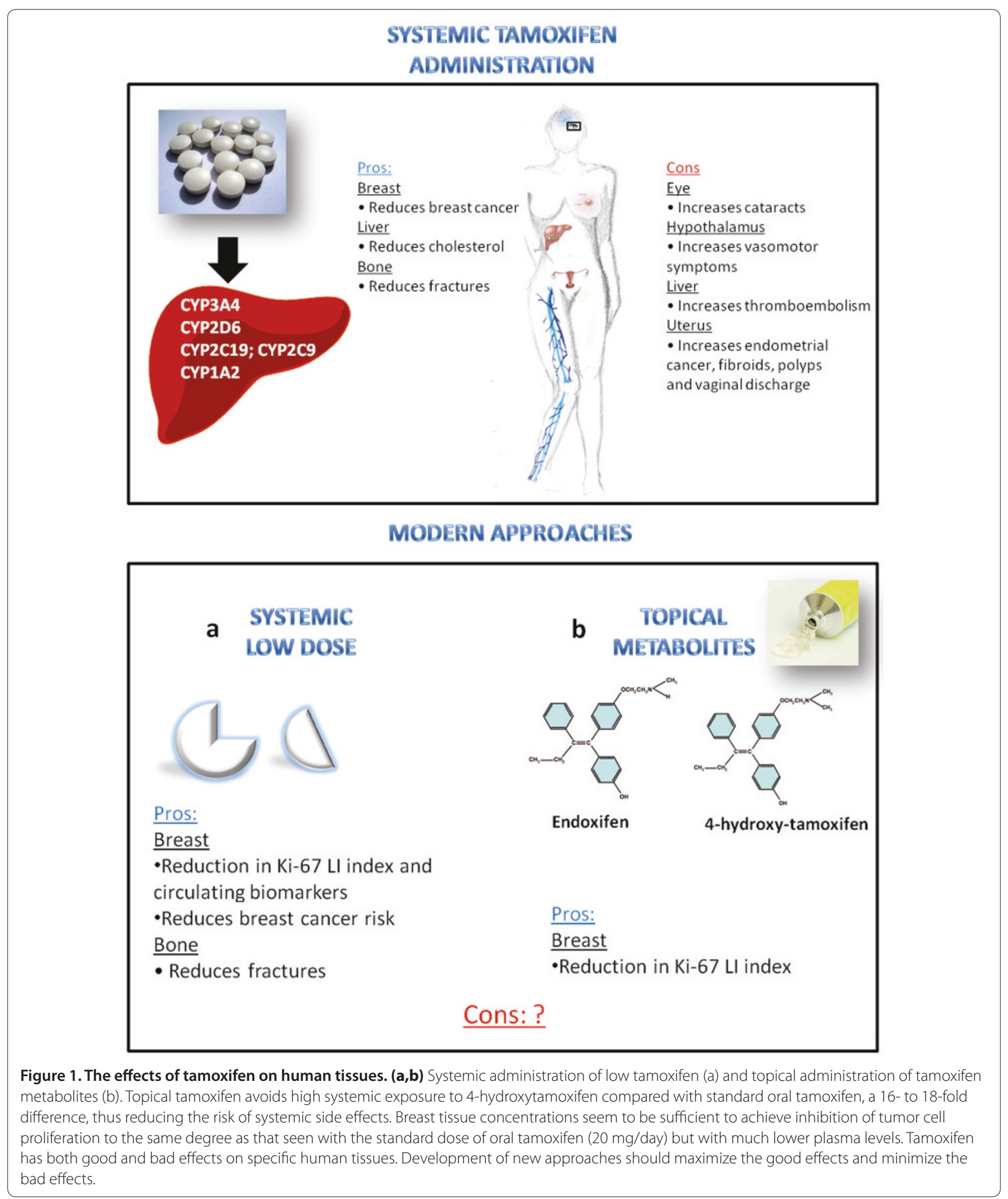

equivalent to that of higher doses of the drug (that is, 30 to $40 \mathrm{mg} /$ day) [3]. Clinical studies addressing the minimal active dose of tamoxifen have not been conducted so far. On the other hand, data from animal studies indicate that reducing the tamoxifen dose to the human-equivalent dose of $1 \mathrm{mg} /$ day does not diminish the drug's inhibitory activity on mammary tumor formation [4]. Additional preclinical evidence has shown that the antitumor effect 
Table 1. Summary of the main published trials on low dose tamoxifen

\begin{tabular}{|c|c|c|c|c|c|}
\hline Study & Treatment & $\begin{array}{l}\text { Number of } \\
\text { patients }\end{array}$ & Population & Primary endpoint & Comment \\
\hline $\begin{array}{l}\text { Breuer et al. } \\
1998[80]\end{array}$ & $\begin{array}{l}\text { TAM } 20 \text { mg/day (91\%) } \\
\text { TAM } 10 \text { mg/day (9\%) }\end{array}$ & $\begin{array}{l}1,385 \\
\text { matched } \\
\text { with 5,196 } \\
\text { controls }\end{array}$ & Women 65 years and older & Bone fracture & $\begin{array}{l}\text { Although standard treatment } \\
\text { of } 20 \mathrm{mg} \text { TAM daily offers no } \\
\text { apparent protection against bone } \\
\text { fracture in older nursing home } \\
\text { residents, a daily } 10 \mathrm{mg} \text { dose } \\
\text { seems to be protective }\end{array}$ \\
\hline $\begin{array}{l}\text { Decensi et al. } \\
1998 \text { [11] }\end{array}$ & $\begin{array}{l}\text { Placebo } \\
\text { TAM } 20 \text { mg/day } \\
\text { TAM } 10 \text { mg/day } \\
\text { TAM } 10 \text { mg alternate } \\
\text { days }\end{array}$ & 127 & $\begin{array}{l}\text { Healthy women } \\
\text { Hysterectomized } \\
35 \text { to } 70 \text { years }\end{array}$ & $\begin{array}{l}\text { Total cholesterol (primary) } \\
\text { Surrogate markers of } \\
\text { cardiovascular disease, IGF-I }\end{array}$ & $\begin{array}{l}\text { Up to a } 75 \% \text { reduction in the } \\
\text { conventional dose of TAM (that } \\
\text { is, } 20 \mathrm{mg} / \text { day) does not affect } \\
\text { the activity of the drug on a large } \\
\text { number of biomarkers, most of } \\
\text { which are surrogate markers of } \\
\text { cardiovascular disease }\end{array}$ \\
\hline $\begin{array}{l}\text { Decensi et al. } \\
2003 \text { [26] } \\
\text { Decensi et al. } \\
2010 \text { (f-up) [30] }\end{array}$ & $\begin{array}{l}\text { TAM } 1 \text { mg/day } \\
\text { TAM } 5 \text { mg/day } \\
\text { TAM } 20 \text { mg/day }\end{array}$ & 120 & $\begin{array}{l}\text { ER+, BC patients } \\
4 \text { weeks before surgery }\end{array}$ & Ki-67 modulation & $\begin{array}{l}\text { Ki-67 expression decreased to } \\
\text { a similar degree among the } \\
\text { three TAM dose groups. Ki-67 } \\
\text { expression after short-term TAM } \\
\text { is a good predictor of recurrence- } \\
\text { free survival and overall survival }\end{array}$ \\
\hline $\begin{array}{l}\text { Decensi et al. } \\
2009 \text { [35] }\end{array}$ & $\begin{array}{l}\text { TAM } 5 \text { mg/day } \\
\text { FEN } 200 \text { mg/day } \\
\text { TAM + FEN } \\
\text { Placebo }\end{array}$ & 235 & $\begin{array}{l}\text { Premenopausal women } \\
\text { pT1mic/pT1a BC; } \\
\text { OR Intraepithelial neoplasia; } \\
\text { OR Gail risk at five years } \\
\geq 1.3 \%\end{array}$ & $\begin{array}{l}\text { Plasma IGF-I } \\
\text { Mammographic density; } \\
\text { uterine effects; breast } \\
\text { neoplastic events after } \\
5.5 \text { years }\end{array}$ & $\begin{array}{l}\text { Despite favorable effects } \\
\text { on plasma IGF-I levels and } \\
\text { mammographic density, the } \\
\text { combination of low-dose TAM } \\
\text { plus FEN did not reduce breast } \\
\text { neoplastic events }\end{array}$ \\
\hline $\begin{array}{l}\text { Bonanni et al. } \\
2009[41]\end{array}$ & $\begin{array}{l}\text { ANA } 1 \text { mg/day } \\
\text { TAM } 10 \text { mg/week } \\
\text { ANA + TAM }\end{array}$ & 75 & $\begin{array}{l}\text { Postmenopausal women } \\
\text { with previous breast } \\
\text { intraepithelial neoplasia }\end{array}$ & $\begin{array}{l}\text { Plasma drug concentrations } \\
\text { Biomarker modulation }\end{array}$ & $\begin{array}{l}\text { The addition of weekly TAM } \\
\text { administration did not impair } \\
\text { anastrozole bioavailability and } \\
\text { modulated favorably its safety } \\
\text { profile }\end{array}$ \\
\hline $\begin{array}{l}\text { Guerrieri Gonzaga } \\
\text { et al. } 2010 \text { [49] }\end{array}$ & $\begin{array}{l}\text { TAM } 20 \text { mg/week } \\
\text { TAM } 5 \text { mg/day }\end{array}$ & 680 & Women with previous DIN & $\begin{array}{l}\text { Second primary breast } \\
\text { cancer (in situ or invasive) }\end{array}$ & $\begin{array}{l}\text { High ER and especially high PgR } \\
\text { expression is a significant adverse } \\
\text { prognostic indicator of DIN, and } \\
\text { low-dose TAM appears to be an } \\
\text { active treatment. Women with } \\
\text { low-expression ER or PgR DIN do } \\
\text { not seem to benefit from TAM }\end{array}$ \\
\hline
\end{tabular}

ANA, anastrozole; BC, breast cancer; DIN, ductal intraepithelial neoplasia; ER, estrogen receptor; ER+, estrogen-receptor positive; FEN, fenretinide; HRT, hormone replacement therapy; IGF, insulin-like grow factor; PgR, progesterone receptor; TAM, tamoxifen.

of the drug reaches a plateau above the concentration that saturates estrogen receptors [5,6].

Given the consistent data from adjuvant therapy trials of a dose- and duration-dependent risk of endometrial cancer during tamoxifen treatment [7-9] and taking into account the long plasma half life ( 4 to 11 days after the steady state is reached [10]), dose reduction and intermittent administration offer plausible ways to improve 
the safety profile of tamoxifen. Together, all these observations suggest that the use of lower doses of the drug offers a reasonable approach to minimizing toxicity while retaining activity.

\section{Clinical trials of low-dose tamoxifen}

To ascertain whether a reduction in the conventional dose of $20 \mathrm{mg} /$ day is associated with diminished biologic activity, Decensi and colleagues [11] assessed the effects of different doses of tamoxifen on a variety of biomarkers known to reflect the pharmacodynamic activity of tamoxifen on different target tissues. These biomarkers include the blood lipid profile [12], blood cell count $[13,14]$, osteocalcin [15], fibrinogen and antithrombin III $[13,14]$, and circulating insulin-like growth factor (IGF)-I $[16,17]$. Importantly, some of these biomarkers have been implicated as putative surrogate biomarkers of breast cancer risk. For instance, experimental evidence indicates that when activated, the growth hormone/IGF-I axis not only promotes proliferation of breast cancer cells $[17,18]$, but also stimulates proliferation of normal breast epithelial cells [19]. Furthermore, a positive association between circulating IGF-I concentration and risk of breast cancer was found in a nested case-control study within the prospective Nurses' Health Study cohort [20], which was recently confirmed by an analysis of pooled individual data of 17 prospective studies [21].

Decensi and colleagues performed two experiments to assess the effect of low-dose tamoxifen in 127 healthy hysterectomized women aged 35 to 70 years, randomly assigned to placebo $(\mathrm{n}=31)$ or tamoxifen $20 \mathrm{mg} /$ day $(\mathrm{n}=30)$ (first experiment), and tamoxifen $10 \mathrm{mg} /$ day $(\mathrm{n}=34)$ or tamoxifen $10 \mathrm{mg}$ alternate days $(\mathrm{n}=32)$ (second experiment) [11]. Baseline and 2-month measurements were compared for total cholesterol (primary endpoint) and other surrogate markers of cardiovascular disease and, in a subgroup of 103 women, IGF-I.

Reduction in the conventional dose of tamoxifen $(20 \mathrm{mg} /$ day) by up to $75 \%$ did not affect the activity of the drug on a large number of biomarkers, most of which are surrogate markers of cardiovascular disease. In particular, after adjustment for the baseline values, there were reductions in circulating levels of total cholesterol and IGF-I of the same magnitude in all three tamoxifen treatment arms.

Further analysis focused on the effect of low-dose tamoxifen on the IGF system [22]. No significant concentration-response relationship was observed between serum tamoxifen concentration and the biomarker changes except for the ratio of IGF-I/IGF binding protein (IGFBP)-3, which decreased by $1.53 \%( \pm 0.68 \%$; $P=0.02)$ for each increase of $10 \mathrm{ng} / \mathrm{ml}$ in serum tamoxifen concentration [22].

A further investigation of the pharmacodynamic properties of tamoxifen at lower doses in a prevention setting involved a study of the effect on levels of ultrasensitive C-reactive protein (CRP), an index of lowgrade vascular inflammation and an important risk marker for cardiovascular disease [23]. Tamoxifen at low doses is able to lower ultrasensitive CRP and this might be associated with a beneficial effect on cardiovascular disease [24].

In a 2003 study, de Lima and colleagues [25] compared the effects of low tamoxifen doses for 50 days on breast biomarkers measured in normal breast tissue from 56 premenopausal women with diagnoses of fibroadenoma of the breast. Excisional biopsy was performed on the 50th day of therapy, and normal breast tissue samples were collected during surgery. Patients had been randomized in double-blind fashion to the following groups: group A, placebo $(\mathrm{n}=11)$; group $\mathrm{B}$, tamoxifen $5 \mathrm{mg}$ $(\mathrm{n}=16)$; group $\mathrm{C}$, tamoxifen $10 \mathrm{mg}(\mathrm{n}=14)$; and group $\mathrm{D}$, tamoxifen $20 \mathrm{mg}(\mathrm{n}=15)$. In this study, differences in the observed changes in expression of estrogen receptor (ER) alpha, progesterone receptor (PgR), Ki-67 labeling index (LI), apoptotic bodies and mitotic indices among the four different groups following treatment were seen in the normal breast tissue. No difference was noted among groups $\mathrm{B}, \mathrm{C}$, and $\mathrm{D}$ in post-treatment values for Ki-67 LI. These observations led the authors to conclude that a lower dose of tamoxifen, which is expected to be associated with fewer side effects, would not have a negative impact on the drug's chemopreventive activity in the breast [25].

In the same year, Decensi and colleagues [26] analyzed the effects of tamoxifen at $1 \mathrm{mg} /$ day and $5 \mathrm{mg} /$ day relative to those of the standard dose of $20 \mathrm{mg} /$ day on Ki-67 LI in breast tumor specimens using a presurgical model. The term 'presurgical' is used to describe a preoperative treatment of short duration (typically 2 to 4 weeks) before surgery, otherwise referred to as a 'window of opportunity' study. This approach can be used for any size of cancer provided it can be core biopsied, and the endpoints are molecular markers. The goals of testing a preventive agent using the presurgical model include: evaluation of target modulation after short drug exposure ( 2 to 4 weeks); pharmacokinetic assessment of a potential anticancer agent; and evaluation of markers that identify subsets of patients who are likely to benefit from the intervention, thereby laying the groundwork for subsequent targeting of appropriate patients in clinical trials that are powered to detect changes in clinical outcome.

The term 'neoadjuvant' is used to describe preoperative treatment for at least 2 months or longer for large cancers (typically $\geq 3 \mathrm{~cm}$ ). Clinical response and pathological complete response are the main endpoints. Traditional goals of neoadjuvant therapy include downstaging to allow conservative surgery, identification of response biomarkers, and ultimately survival benefit. At variance, the 
presurgical window of opportunity studies will not lead to downstaging and clinical and pathological response rates are unrealistic objectives.

One hundred and twenty women with ER-positive breast cancer were randomly assigned to tamoxifen at 1 , 5 , or $20 \mathrm{mg} /$ day for 4 weeks before surgery. Additionally, Ki-67 was evaluated in two nonrandomized control groups who did not receive tamoxifen (34 women with ER-negative breast cancer and 29 additional women with ER-positive breast cancer). Expression of Ki-67 decreased in all three tamoxifen dose-level groups, with no difference in the magnitude of reduction among the groups $(P=0.81)$. A dose-concentration relationship was observed for levels of tamoxifen and its metabolites in serum and cancer tissue. Preferential accumulation of tamoxifen in the breast was suggested by the observation that the concentrations in this tissue were 2 to 15 times the levels of drug and metabolites seen in the corresponding serum samples. Of note, a tamoxifen dose of $1 \mathrm{mg} /$ day resulted in levels of 4-hydroxytamoxifen (4-OHT) in tissue that were approximately 10 to 20 times greater than the $50 \%$ inhibitory concentration range observed in a number of MCF-7 breast cancer cell clones after 48 to 72 hours, namely, 0.5 to $5 \mathrm{nM}$, or 0.2 to $2 \mathrm{ng} / \mathrm{ml}$ [27].

Recently, short-term intervention with tamoxifen prior to surgery has shown that, following drug treatment, Ki67 levels have prognostic significance for progressionfree survival at the standard dose as well as at lower doses [28-30]. This low-dose ranging study, after 7.2 years of follow-up [30], showed that women whose post-treatment Ki-67 LIs were in the second (14 to 19\%), third (20 to $29 \%$ ) and top ( $\geq 30 \%)$ quartiles had a hazard ratio (HR) for recurrence of 2.92 (95\% confidence interval (CI), 0.95 to 8.96 ), 4.37 (95\% CI 1.56 to 12.25 ) and 6.05 (95\% CI 2.07 to 17.65$)$, respectively, when compared with those in the bottom quartile (Ki-67 LI <14\%) (p-trend = 0.001). Ki-67 response after short-term presurgical tamoxifen was a good predictor of recurrence-free survival and overall survival, further supporting its use as a surrogate endpoint biomarker to tailor adjuvant treatment to the individual patient and to screen novel drugs in a costeffective manner.

\section{Clinical trials of low dose tamoxifen in combination with other agents \\ Tamoxifen and fenretinide}

The hypothesis that tamoxifen and fenretinide offer a potentially beneficial combination derived from animal studies showing a synergistic effect of the two agents on the inhibition of mammary carcinogenesis [31,32]. A phase III clinical trial showed that the potential preventive efficacy of fenretinide was evident only in premenopausal women [33]. Based on these findings, a randomized double-blind $2 \times 2$ factorial design trial was implemented [34,35]. A total of 235 premenopausal women diagnosed with $\mathrm{pT} 1 \mathrm{mic} / \mathrm{pT} 1 \mathrm{a}$ breast cancer or intraepithelial neoplasia, or 5 -year Gail risk $\geq 1.3 \%$ were randomly allocated to tamoxifen $5 \mathrm{mg} /$ day, fenretinide $200 \mathrm{mg} /$ day, their combination, or placebo. During the 2-year intervention, tamoxifen significantly lowered IGFI and mammographic density by $12 \%$ and $20 \%$, respectively, fenretinide lowered them by $4 \%$ and $10 \%$ (not significantly), and their combination did so by $20 \%$ and $22 \%$, with no evidence for a synergistic interaction. The combination of low-dose tamoxifen plus fenretinide did not reduce breast neoplastic events compared to placebo, whereas both single agents, particularly fenretinide, showed numerical reduction of breast neoplasms [34,35].

\section{Tamoxifen and aromatase inhibitors}

Aromatase inhibitors have become the standard treatment for ER-positive breast cancer in postmenopausal women [36,37]. Two of the three third generation aromatase inhibitors (anastrozole and exemestane) are being tested - and one (exemestane) has recently been shown to be effective - as chemopreventive agents in high-risk women [38]. Despite their promise for risk reduction, these agents are associated with increased rates of bone fracture, joint and tendon disorders, and possibly increased cardiovascular risk due to their profound estrogen-suppressive effect. Moreover, prolonged aromatase inhibitor treatment may lead to the onset of endocrine resistance with the emergence of estrogen hypersensitive cell clones [39]. One possible approach to counteracting these adverse side effects, supplementation of the aromatase inhibitor with tamoxifen at the standard dose, has been addressed in the ATAC (Arimidex, Tamoxifen Alone and in Combination) trial $[37,40]$. In this trial, the aromatase inhibitor anastrozole was compared with tamoxifen for 5 years in 9,366 postmenopausal women with localized breast cancer. The combination arm, anastrazole $1 \mathrm{mg} /$ day plus tamoxifen $20 \mathrm{mg} /$ day, was closed prematurely due to a lack of increased efficacy relative to tamoxifen alone. One possible explanation for this effect is that pharmacokinetic interference occurs between the two drugs. Intriguing results were obtained by Bonanni and colleagues [41] in their assessment of whether the addition of a low dose of tamoxifen influenced anastrozole bioavailability. Seventy-five postmenopausal women with breast intraepithelial neoplasia were randomly allocated to anastrozole $1 \mathrm{mg} /$ day, tamoxifen $10 \mathrm{mg} /$ week or a combination of the two for 12 months. Anastrozole concentrations were not affected by combination with low-dose tamoxifen. C-telopeptide levels, a biomarker of bone turnover, increased by $20 \%$ with anastrozole and decreased by $16 \%$ with tamoxifen and by $7 \%$ with the combination $(P<0.001$ for both comparisons); osteocalcin, another marker of bone 
turnover, showed similar changes. With respect to markers of breast cancer risk, compared with anastrozole, the combination arm was associated with a greater reduction in the ratio of IGF-I/IGFBP-3 levels $(-17 \%$ versus $-9 \% ; P=0.004$ ) as well as the ratio of estradiol/sex hormone-binding globulin (SHBG) levels and estrone sulfate levels $(-15 \%$ versus $-29 \%$ and $-30 \%$ versus $-38 \%$, respectively). _Endometrial thickness was not greater in the combination than in the anastrozole arm. In conclusion, the addition of a weekly low dose of tamoxifen did not impair anastrozole bioavailability and favorably modulated its safety profile, providing the rationale for larger studies of this combination treatment.

\section{Tamoxifen and hormone replacement therapy}

In the Italian Tamoxifen Prevention Study, 5,408 healthy hysterectomized women aged 35 to 70 years were randomized to tamoxifen $20 \mathrm{mg} /$ day or placebo for 5 years and hormone replacement therapy (HRT) was allowed [42]. After 81.2 months median follow-up, 79 breast cancers occurred (34 on tamoxifen versus 45 on placebo, $P=0.215$ ) [43]. In the subgroup of 1,580 women who used estrogen replacement therapy at some point during the study, 23 breast cancers were observed: 17 on placebo and 6 on tamoxifen $(\mathrm{HR}=0.35,95 \% \mathrm{CI} 0.14$ to 0.89). Although this analysis had low power, this cohort of women using HRT seemed to benefit from tamoxifen.

The safety and the activity of the combination of lowdose tamoxifen with HRT were studied in a dose ranging trial [44]. The study included 210 current or de novo HRT users who were randomly assigned to one of the following four arms: tamoxifen $1 \mathrm{mg} /$ day, tamoxifen $10 \mathrm{mg} /$ week, tamoxifen $5 \mathrm{mg} /$ day, or placebo for 12 months. The primary endpoint was the change of plasma IGF-I levels through 12 months, and secondary endpoints were IGF-I/ IGFBP-3 ratio, fibrinogen, antithrombin III, CRP, Ctelopeptide, mammographic percent density, and endometrial thickness. Endometrial proliferation was assessed by Pipelle biopsy in superficial, deep glandular, and stromal compartments after 12 months. Compared with placebo, IGF-I (primary endpoint) declined in all tamoxifen arms $(P=0.005)$, with a greater change on $5 \mathrm{mg} /$ day compared to $10 \mathrm{mg} /$ week or $1 \mathrm{mg} /$ day $(P=0.019)$. Among cardiovascular biomarkers, tamoxifen favorably modulated high sensitivity CRP and antithrombin III, but not lipids and fibrinogen, and $5 \mathrm{mg} /$ day was superior to the lower doses in modulating both biomarkers. Importantly, no effect of tamoxifen at low doses was found on endometrial tissue biomarkers. While endometrial thickness was significantly augmented (stromal hypertrophy), this was not associated with histological alterations, nor was there an increase in cell proliferation measured by Ki-67. Menopausal symptoms were not significantly worsened by tamoxifen. In conclusion, doses of tamoxifen $\leq 5 \mathrm{mg} /$ day favorably modulated biomarkers of breast carcinogenesis and cardiovascular risk in HRT users without causing increases in a biomarker of endometrial proliferation and menopausal symptoms. A dose of $5 \mathrm{mg} /$ day was the most effective.

The Hormone Replacement Therapy Opposed by Low Dose Tamoxifen (HOT) study is a multicenter phase III trial in postmenopausal healthy women, current or de novo HRT users, randomized to either tamoxifen $5 \mathrm{mg}$ /day or placebo for 5 years, with 5 years of follow-up. The trial is designed to assess whether the combination of HRT and low-dose tamoxifen retains the benefits while reducing the risks of either agent. The HOT trial completed its accrual in 2007, with 1,884 subjects enrolled [45]. At 7.7 years mean follow-up, 43 breast cancers were diagnosed. A trend toward a beneficial effect from low dose tamoxifen in reducing breast cancer events was observed, with greater efficacy being seen in the ER+, PgR+, Ki-67 <14\% subgroup ( $\mathrm{HR}=0.32 ; 95 \% \mathrm{CI} 0.12$ to 0.86$)$ [46].

\section{Low-dose tamoxifen and intraepithelial neoplasia}

The results of the studies discussed above prompted the introduction in 2004 of low-dose tamoxifen in different forms, $5 \mathrm{mg} /$ day or $10 \mathrm{mg}$ on alternate days or $20 \mathrm{mg}$ per week, into the European Institute of Oncology (EIO) clinical guidelines for management of hormone-responsive ductal carcinoma in situ of the breast, recently renamed ductal intraepithelial neoplasia (DIN) at the EIO [47] in 2004. The cancer prevention group investigated the postsurgical treatment outcomes of women undergoing breast conserving surgery $(\mathrm{n}=974)$ or mastectomy $(n=293)$ at the EIO between 1996 and 2005, with follow-up until December 2006 [48]. A subsequent analysis specifically assessed the effect of low-dose tamoxifen on the incidence of breast cancer events according to the expression levels of ER and PgR [49]. A total of 309 patients with DIN received low-dose tamoxifen and were compared with 371 patients with DIN who received no systemic treatment after surgery. Women with DIN in which both ER and PgR were $>50 \%$ who were not treated experienced a higher incidence of breast events than women with similar ER/PgR levels taking tamoxifen (HR 1.76; 95\% CI 1.00 to 3.12 ) or women with ER and PgR <50\% DIN (HR 1.72; 95\% CI 1.14 to 2.58) receiving or not receiving tamoxifen. Among untreated patients with ER $>50 \%$ DIN, recurrence was higher in PgR $\geq 50 \%$ DIN than in PgR $<50 \%$ DIN. The recurrence rate in the latter group resembled that seen in low PgR $(<50 \%)$ DIN regardless of tamoxifen treatment; tamoxifen conferred no benefit in this low PgR subgroup. No difference in endometrial cancer incidence was noted. In conclusion, high ER and especially high PgR expression was a significant adverse prognostic indicator of recurrence, and low-dose tamoxifen appeared to be an 
effective treatment. Women with low-expression ER or PgR DIN do not seem to benefit from tamoxifen.

\section{Ongoing trials of low-dose tamoxifen}

The utility of preventive low-dose tamoxifen is currently being evaluated in an entirely different cohort of highrisk women: female survivors of Hodgkin lymphoma who were previously treated with $\geq 15$ Gy of mantle irradiation to the chest before age 30 (NCT01196936) [50]. In this phase IIb randomized, double-blind, placebo-controlled trial, 300 eligible women are being randomized to tamoxifen $5 \mathrm{mg} /$ day or to placebo for 2 years. Breast tissue is sampled using random peri-areolar fine needle aspiration both before and at the end of the 2-year treatment period. The primary endpoint of the trial is change in mammographic density.

An Italian multicenter phase III trial is currently ongoing to evaluate the efficacy and safety of tamoxifen $5 \mathrm{mg} /$ day for reducing breast cancer incidence in 1,400 women operated on for lobular intraepithelial neoplasia (LIN 2, 3) or ER-positive DIN (DIN 1 to 3 ; $1 \mathrm{a}$ is excluded) (NCT01357772) [51]. In addition to the primary endpoint of incidence of invasive breast cancer and ductal carcinoma in situ (DIN 1c, 2, 3) of the breast, the study is also examining endometrial cancer, clinical bone fractures, cardiovascular events, venous thromboembolic events, and clinically manifest cataracts and overall mortality.

\section{Localized therapy: topical and intraductal tamoxifen for breast cancer prevention}

\section{Clinical concerns about oral tamoxifen for breast cancer} prevention

Tamoxifen is a pro-drug, requiring conversion by the phase I drug metabolizing cytochrome P450 enzymes, predominantly CYP2D6 but also CYP3A4/5 among others, to its major anti-estrogenic metabolites [52]. Toxicity can result from systemic administration, due to the activity of tamoxifen in non-breast tissues. This offtarget action, often seen with long-term systemic exposure to tamoxifen, is associated with hot flashes, night sweats, and menstrual irregularity, as well as the more serious risks of thromboembolism and endometrial cancer [53]. In women with DIN and those at high risk of breast cancer, effective concentrations are required only in breast tissue; systemic exposure is redundant, and minimization of side effects is essential, since agents offered to healthy high-risk women need to be both safe and well tolerated.

Local percutaneous administration of drugs to the breast: setting the stage for topical tamoxifen for breast cancer prevention

\section{Experience with topical drugs}

Transdermal delivery has long been recognized as an effective alternative to conventional systemic therapy, including oral administration. When delivered transdermally, a drug is characterized by distinct pharmacokinetics, with longer retention in the local tissue. However, due to the effectiveness of the barrier function of the stratum corneum, only a relatively small number of lipophilic drugs with low molecular weights $(<500 \mathrm{Da})$ have been successfully formulated for these purposes. Among the drugs delivered successfully by the percutaneous route, the reproductive hormones, including HRT and contraceptive patches, are in standard clinical use. Progesterone was the first hormone tested for local treatment in benign breast diseases $[54,55]$. Topical daily application of progesterone, $50 \mathrm{mg}$ in hydroalcoholic gel for 3 months, was efficacious in treating benign breast diseases (mastodynia, fibroadnomas, and so on) [56,57]. This benefit resulted from local antiestrogenic activity of progesterone in the breast $[54,55]$.

Since tamoxifen is a pro-drug requiring hepatic activation, the transdermal approach may not be suitable per se. A more reasonable approach is to utilize its more active metabolites. Mauvais-Jarvis and colleagues [58] determined that the tamoxifen metabolite 4-OHT, like progesterone, could be concentrated directly in the breast tissue. A pre-surgical study of 12 women with ER-positive breast cancer was undertaken to compare the concentration and metabolism of ${ }^{3} \mathrm{H}$-labeled trans-4-OHT with that of tamoxifen following topical administration to the affected breast for up to 7 days [58]. Surgically resected breast tissue obtained 12 to 24 hours after one topical dose $(80 \mu \mathrm{Ci}$ in $60 \%$ alcoholic solution for each drug) exhibited detectable levels of both 4-OHT and tamoxifen in the breast tumor tissue as well as the surrounding normal mammary tissue. Although the maximal concentration of both 4-OHT and tamoxifen in the breast tissue was reached 24 hours after a topical application, 4-OHT was retained for a much longer period in the breast than was tamoxifen. Plasma kinetics for 4-OHT and tamoxifen revealed that tamoxifen appeared in plasma more rapidly and decreased faster than did 4-OHT, possibly related to the lower affinity of tamoxifen for the ER present in breast tumors and breast epithelium.

Moreover, 4-OHT exhibited site-dependent retention, showing higher retention in breast tissue compared to the abdomen, arm or shoulder [59]. The investigators attributed this differential accumulation to the binding of 4-OHT to ERs present in breast tumors and breast epithelium. However, receptor binding alone is insufficient to explain 4-OHT retention in the breast [60]. A more plausible explanation relates to the embryological origin of the breast as a skin appendage (that is, a modified sweat or apocrine gland). The breast gland (parenchyma) and its skin envelope develop embryologically as a single unit with a well-developed internal lymphatic (and venous) circulation [61]. These embryological observations are 
supported by the common drainage patterns of the skin and parenchyma of the breast; both drain into the same sentinel lymph nodes [62]. This mutual drainage of skin and parenchyma predicts that other drugs applied to the skin of the breast should also concentrate in the parenchyma to a greater degree than would be expected based on systemic absorption and delivery through the circulation.

Preclinical studies have been comparing 4-OHT with endoxifen, which is expected to have a stronger antiestrogenic effect [63]. However, the permeation of endoxifen into human skin was not as efficient as that of 4-OHT in a vehicle of $60 \%(\mathrm{v} / \mathrm{v})$ ethanol-phosphate buffer. The addition of $1 \%(\mathrm{v} / \mathrm{v})$ oleic acid greatly improved permeation of endoxifen over a 24-hour period [64].

\section{Proof-of-principle studies paving the way for topical tamoxifen}

Investigations that lay the groundwork for using tamoxifen locally include studies on mastalgia and one presurgical (window-of-opportunity) trial.

In the setting of mastalgia, several European studies have examined the relief of breast pain or tenderness following topical application of a hydro-alcoholic gel of 4-OHT (Besins, France). Most recently, a randomized phase II trial compared a placebo control group to two treated groups ( $4 \mathrm{mg} /$ day and $2 \mathrm{mg} /$ day) for 4 months with respect to a primary efficacy endpoint of change in mean pain intensity as measured by the Visual Analog Scale [65]. The Visual Analog Scale results showed a statistically significant improvement with the 4-OHT gel at a $4 \mathrm{mg} /$ day concentration for four menstrual cycles, despite the fact that the resulting average plasma levels of 4-OHT, $50 \pm 64 \mathrm{pg} / \mathrm{ml}$ (mean \pm standard deviation), were much lower than the levels seen with oral tamoxifen. Systemic side effects, such as hot flashes and headache, were infrequent. Thus, 4-OHT gel delivered potent and sustained antiestrogenic effects to target tissue while avoiding the side effects associated with first-pass metabolism of tamoxifen.

The potential chemopreventive effect of topical application of 4-OHT was tested by Rouanet and colleagues [66] in a presurgical trial of 55 postmenopausal women with T1 or T2 invasive ER-positive breast cancer. Following randomization into five groups, patients were treated for 2 to 3 weeks; three groups received topical 4-OHT gels (0.5, 1 , or $2 \mathrm{mg} /$ breast/day), one group received oral tamoxifen $(20 \mathrm{mg} /$ day $)$, and the fifth group received no treatment. The primary endpoints were reductions in the tumor tissue proliferation indices, Ki-67 and PCNA (proliferating cell nuclear antigen). Among the 45 patients assessable for efficacy, the treatment groups were compared with respect to differences in tumor tissue Ki-67 levels between baseline and after 2 to 3 weeks of treatment [66]. Drug-treated groups (topical 4-OHT gels and oral tamoxifen) showed a significant decrease in median Ki-67 levels relative to the notreatment group $(P=0.0055)$. No significant dosedependent difference in reduction of Ki-67 levels was observed among the three topical 4-OHT groups $(P=0.07$; median values of reduction in Ki-67 levels were -3.8 for oral tamoxifen $(20 \mathrm{mg} /$ day, $\mathrm{n}=10)$ and $-0.8,-4.5$, -3.9 for 4-OHT gels $0.5 \mathrm{mg} /$ day $(\mathrm{n}=8), 1 \mathrm{mg} /$ day $(\mathrm{n}=9)$, and $2 \mathrm{mg} /$ day $(\mathrm{n}=8)$, respectively. When applied to breast skin daily, 1 or $2 \mathrm{mg}$ 4-OHT hydroalcoholic gel therefore resulted in sufficient breast tissue concentrations to achieve inhibition of tumor cell proliferation to the same degree as seen with the standard dose of oral tamoxifen $(20 \mathrm{mg} /$ day $)$ but with much lower plasma levels. Hot flushes were reported in the oral tamoxifen group and the 1 and $2 \mathrm{mg} /$ day gel treatment groups, whereas no side effects were experienced in the $0.5 \mathrm{mg} /$ day and no treatment groups. Importantly, all patients were postmenopausal women who experienced some level of baseline hot flushing. Yet, an exacerbation related to systemic exposure to 4-OHT cannot be ruled out, since this was a very short-term study and low plasma levels were achieved, suggesting some systemic effect. In conclusion, percutaneous 4-OHT gel had a local impact on tumor proliferation, suggesting its possible use in future prospective trials of chemoprevention.

\section{Phase II-B study of 4-OHT gel in women with DIN}

The same formulation of 4-OHT that was used (Besins, France) in prior studies $[65,66]$ was incorporated by Khan and colleagues into an NCI/DCP supported multi-center presurgical study in women with DIN (NCT00952731) [67] in the US. Women with ER-positive DIN based on a core-biopsy diagnosis were randomized to either oral tamoxifen $20 \mathrm{mg} /$ day or a 4-OHT gel at a dose of $4 \mathrm{mg} /$ breast/day that is applied topically once daily for 6 to 10 weeks. The primary endpoint, decreased cell proliferation in the DIN lesion, is reflected in the Ki-67 level. Additional parameters of interest include breast versus systemic concentrations of 4-OHT and its isomers, effects on the coagulation cascade, and the occurrence of hot flushes. Analyses of blood and tissue specimens collected from 22 women are currently being carried out. This study is expected to provide data on the efficacy and tolerability of topical 4-OHT at a dose twice that used in the prior study by Rouanet and colleagues [66] and to offer more extensive information relating to toxicity, especially hot flushes and hypercoagulability. Exploratory analyses of tamoxifen metabolism genotypes in relation to efficacy, tolerability and coagulability are also planned. The treatment interval is too short to assess uterine effects.

\section{Intraductal instillation of tamoxifen metabolites}

Intraductal instillation of 4-OHT or endoxifen offers yet another localized approach to prevention. The feasibility 
of this method is evident in its use in the treatment setting. In a recently completed phase I study, successful intraductal administration of pegylated liposomal doxorubicin was carried out in 15 of the 17 women 2 to 4 weeks prior to surgery for early stage breast cancer. The failures of intraductal administration were due to extent of disease or previous excisional biopsy [68]. Of interest, preclinical intraductal administration of 4-OHT has been shown in the N-methyl-N-nitrosourea-induced rat model of ER-positive breast cancer to prevent tumorigenesis [69]. The same intraductal approach is being applied in the prevention setting in a pilot study of women with core biopsy-documented DIN using an intraductal injection of pegylated liposomal doxorubicin followed by 4 to 6 weeks of observation prior to definitive surgery (NCT00671476) [70].

\section{Conclusions}

Tamoxifen for use in the breast cancer prevention setting is supported by strong evidence, including phase III clinical trials. Based on clinical trial data, tamoxifen was approved for risk reduction by the US Food and Drug Administration (FDA) in 1998, and it has been endorsed for this purpose in specific categories of women by the American Society of Clinical Oncology Clinical Practice Guidelines committee [2,71,72]. In spite of these supporting factors, tamoxifen continues to have low acceptability in the community of high-risk women and their physicians, who are primarily non-oncologists [4,73-75]. This limited uptake of tamoxifen for prevention has been attributed primarily to concerns about drug toxicities and a perceived unfavorable balance between risks and benefits. These concerns about drug toxicity are exacerbated by the lack of experience with oncology drugs among the internists, gynecologists and family practitioners who generally see and counsel high-risk women. These primary care physicians are often reluctant to prescribe tamoxifen, which they perceive as a 'cancer drug' that has challenging side effects.

In order to reduce the risk of these adverse events, effective and safer drugs are being developed that could potentially replace tamoxifen as preventive agents in high-risk women. Novel endocrine agents, including both newer selective ER modulators (raloxifene) [76] and, more recently, third generation aromatase inhibitors (exemestane and anastrozole) [38,77], have been or are being evaluated in phase III clinical trials as breast cancer risk-reducing agents. All of these drugs, however, are limited to postmenopausal women, leaving tamoxifen as the only chemopreventive drug for premenopausal women who are at increased risk of breast cancer.

Both low dose tamoxifen and topical transdermal application of tamoxifen metabolites offer two promising strategies for reducing side effects relative to standard dose oral tamoxifen in the breast cancer prevention setting. Several phase II trials have demonstrated that low-dose tamoxifen retains biological activity while potentially having lower toxicity. These clinical trial findings, together with data from observational studies, suggest clinical value of low-dose tamoxifen for prevention $[26,35,41,44,49]$. The ongoing phase III trials will help to define more clearly the risk:benefit ratio of lowdose tamoxifen.

Topical applications are of great interest but drug formulation and dosage require close examination. Following transdermal application of 4-OHT in the studies conducted so far, very low plasma concentrations of the drug have been observed. These low plasma levels in the setting of a topical approach that bypasses first-pass metabolism in the liver suggest that there should be a reduction in systemic toxicity $[58,59,65,78,79]$. Together, these features strongly support the development of localized interventions for breast cancer prevention.

\section{Abbreviations}

4-OHT, 4-hydroxytamoxifen; Cl, confidence interval; CRP, C-reactive protein; DIN, ductal intraepithelial neoplasia; EIO, European Institute of Oncology; ER, estrogen receptor; HR, hazard ratio; HRT, hormone replacement therapy; IGF, insulin-like growth factor; IGFBP, insulin-like growth factor binding protein; LI, labeling index; PgR, progesterone receptor.

\section{Author details}

'Divisions of Cancer Prevention and Genetics, European Institute of Oncology, Milan, 20141 Italy. ${ }^{2}$ Division of Cancer Prevention, National Cancer Institute, Bethesda, MD 20892, USA. ${ }^{3}$ Department of Surgery, Robert H Lurie Comprehensive Cancer Center, Northwestern University, Chicago, IL 60611, USA. ${ }^{4}$ Division of Medical Oncology, EO Ospedali Galliera, Genoa, 16128 Italy.

\section{Published: 29 October 2012}

\section{References}

1. Colleoni M, Gelber S, Goldhirsch A, Aebi S, Castiglione-Gertsch M, Price KN, Coates AS, Gelber RD: Tamoxifen after adjuvant chemotherapy for premenopausal women with lymph node-positive breast cancer: International Breast Cancer Study Group Trial 13-93. J Clin Oncol 2006, 24:1332-1341.

2. Fisher B, Costantino JP, Wickerham DL, Cecchini RS, Cronin WM, Robidoux A, Bevers TB, Kavanah MT, Atkins JN, Margolese RG, Runowicz CD, James JM, Ford LG, Wolmark N: Tamoxifen for the prevention of breast cancer: current status of the National Surgical Adjuvant Breast and Bowel Project P-1 study. J Natl Cancer Inst 2005, 97:1652-1662.

3. Early Breast Cancer Trialists' Collaborative Group: Tamoxifen for early breast cancer: an overview of the randomised trials. Lancet 1998, 351:1451-1467.

4. Maltoni C, Minardi F, Belpoggi F, Pinto C, Lenzi A, Filippini F: Experimental results on the chemopreventive and side effects of tamoxifen using a human-equivalent animal model. In The Scientific Bases of Cancer Chemoprevention. Edited by Maltoni C, Soffritti M, Davis W. Elsevier Science BV; 1996:197-207.

5. Coezy E, Borgna JL, Rochefort H: Tamoxifen and metabolites in MCF7 cells: correlation between binding to estrogen receptor and inhibition of cell growth. Cancer Res 1982, 42:317-323.

6. Sutherland RL, Watts CK, Hall RE, Ruenitz PC: Mechanisms of growth inhibition by nonsteroidal antioestrogens in human breast cancer cells. J Steroid Biochem 1987, 27:891-897.

7. Fisher B, Costantino JP, Redmond CK, Fisher ER, Wickerham DL, Cronin WM: Endometrial cancer in tamoxifen-treated breast cancer patients: findings from the National Surgical Adjuvant Breast and Bowel Project (NSABP) B-14. J Nat/ Cancer Inst 1994, 86:527-537.

8. Rutqvist LE, Johansson H, Signomklao T, Johansson U, Fornander T, Wilking N: Adjuvant tamoxifen therapy for early stage breast cancer and second primary malignancies. Stockholm Breast Cancer Study Group. J Natl Cancer 
Inst 1995, 87:645-651.

9. van Leeuwen FE, Benraadt J, Coebergh JW, Kiemeney LA, Gimbrere CH, Otter R, Schouten LJ, Damhuis RA, Bontenbal M, Diepenhorst FW: Risk of endometrial cancer after tamoxifen treatment of breast cancer. Lancet 1994, 343:448-452.

10. Lonning PE, Lien EA: Pharmacokinetics of anti-endocrine agents. Cancer Surv 1993, 17:343-370.

11. Decensi A, Bonanni B, Guerrieri-Gonzaga A, Gandini S, Robertson C, Johansson $H$, Travaglini R, Sandri MT, Tessadrelli A, Farante G, Salinaro F, Bettega D, Barreca A, Boyle P, Costa A, Veronesi U: Biologic activity of tamoxifen at low doses in healthy women. J Natl Cancer Inst 1998, 90:1461-1467.

12. Love RR, Wiebe DA, Feyzi JM, Newcomb PA, Chappell RJ: Effects of tamoxifen on cardiovascular risk factors in postmenopausal women after 5 years of treatment. J Nat/ Cancer Inst 1994, 86:1534-1539.

13. Mannucci PM, Bettega D, Chantarangkul V, Tripodi A, Sacchini V, Veronesi U: Effect of tamoxifen on measurements of hemostasis in healthy women. Arch Intern Med 1996, 156:1806-1810.

14. Love RR, Surawicz TS, Williams EC: Antithrombin III level, fibrinogen level, and platelet count changes with adjuvant tamoxifen therapy. Arch Intern Med 1992, 152:317-320

15. Love RR, Mazess RB, Barden HS, Epstein S, Newcomb PA, Jordan VC, Carbone PP, DeMets DL: Effects of tamoxifen on bone mineral density in postmenopausal women with breast cancer. NEngl J Med 1992, 326:852-856.

16. Colletti RB, Roberts JD, Devlin JT, Copeland KC: Effect of tamoxifen on plasma insulin-like growth factor I in patients with breast cancer. Cancer Res 1989 49:1882-1884.

17. Pollak M, Costantino J, Polychronakos C, Blauer SA, Guyda H, Redmond C, Fisher $B$, Margolese R: Effect of tamoxifen on serum insulinlike growth factor I levels in stage I breast cancer patients. J Nat/ Cancer Inst 1990, 82:1693-1697.

18. Yang XF, Beamer WG, Huynh H, Pollak M: Reduced growth of human breast cancer xenografts in hosts homozygous for the lit mutation. Cancer Res 1996, 56:1509-1511.

19. Ng ST, Zhou J, Adesanya OO, Wang J, LeRoith D, Bondy CA: Growth hormone treatment induces mammary gland hyperplasia in aging primates. Nat Med 1997, 3:1141-1144.

20. Hankinson SE, Willett WC, Colditz GA, Hunter DJ, Michaud DS, Deroo B, Rosner $B$, Speizer FE, Pollak M: Circulating concentrations of insulin-like growth factor-I and risk of breast cancer. Lancet 1998, 351:1393-1396.

21. Key TJ, Appleby PN, Reeves GK, Roddam AW: Insulin-like growth factor 1 (IGF1), IGF binding protein 3 (IGFBP3), and breast cancer risk: pooled individual data analysis of 17 prospective studies. Lancet Onco/ 2010 11:530-542

22. Bonanni B, Johansson H, Gandini S, Guerrieri-Gonzaga A, Torrisi R, Sandri MT, Cazzaniga M, Mora S, Robertson C, Lien EA, Decensi A: Effect of low dose tamoxifen on the insulin-like growth factor system in healthy women. Breast Cancer Res Treat 2001, 69:21-27.

23. Ridker PM, Rifai N, Rose L, Buring JE, Cook NR: Comparison of C-reactive protein and low-density lipoprotein cholesterol levels in the prediction of first cardiovascular events. N Engl J Med 2002, 347:1557-1565.

24. Bonanni B, Johansson H, Gandini S, Guerrieri-Gonzaga A, Sandri MT, Mariette F, Lien EA, Decensi A: Effect of tamoxifen at low doses on ultrasensitive Creactive protein in healthy women. J Thromb Haemost 2003, 1:2149-2152.

25. de Lima GR, Facina G, Shida JY, Chein MB, Tanaka P, Dardes RC, Jordan VC, Gebrim LH: Effects of low dose tamoxifen on normal breast tissue from premenopausal women. Eur J Cancer 2003, 39:891-898.

26. Decensi A, Robertson C, Viale G, Pigatto F, Johansson H, Kisanga ER, Veronesi P, Torrisi R, Cazzaniga M, Mora S, Sandri MT, Pelosi G, Luini A, Goldhirsch A, Lien $\mathrm{EA}$, Veronesi $\mathrm{U}$ : A randomized trial of low-dose tamoxifen on breast cancer proliferation and blood estrogenic biomarkers. J Natl Cancer Inst 2003, 95:779-790.

27. Greenberger LM, Annable T, Collins KI, Komm BS, Lyttle CR, Miller CP, Satyaswaroop PG, Zhang Y, Frost P: A new antiestrogen, 2-(4-hydroxyphenyl)-3-methyl-1-[4-(2-piperidin-1-yl-ethoxy)-benzyl]-1H-indol-5-ol hydrochloride (ERA-923), inhibits the growth of tamoxifen-sensitive and -resistant tumors and is devoid of uterotropic effects in mice and rats. Clin Cancer Res 2001, 7:3166-3177.

28. Dowsett M, Smith IE, Ebbs SR, Dixon JM, Skene A, A'Hern R, Salter J, Detre S, Hills M, Walsh G: Prognostic value of Ki67 expression after short-term presurgical endocrine therapy for primary breast cancer. J Natl Cancer Inst 2007, 99:167-170.

29. Ellis MJ, Tao Y, Luo J, A'Hern R, Evans DB, Bhatnagar AS, Chaudri Ross HA, von KA, Miller WR, Smith I, Eiermann W, Dowsett M: Outcome prediction for estrogen receptor-positive breast cancer based on postneoadjuvant endocrine therapy tumor characteristics. J Nat C Cancer Inst 2008, 100:1380-1388.

30. Decensi A, Guerrieri-Gonzaga A, Gandini S, Serrano D, Cazzaniga M, Mora S, Johansson H, Lien EA, Pruneri G, Viale G, Bonanni B: Prognostic significance of Ki-67 labeling index after short-term presurgical tamoxifen in women with ER-positive breast cancer. Ann Oncol 2010, 22:582-587.

31. Ratko TA, Detrisac CJ, Dinger NM, Thomas CF, Kelloff GJ, Moon RC: Chemopreventive efficacy of combined retinoid and tamoxifen treatment following surgical excision of a primary mammary cancer in female rats. Cancer Res 1989, 49:4472-4476.

32. Moon RC, Kelloff GJ, Detrisac CJ, Steele VE, Thomas CF, Sigman CC: Chemoprevention of MNU-induced mammary tumors in the mature rat by 4-HPR and tamoxifen. Anticancer Res 1992, 12:1147-1153.

33. Veronesi U, De Palo G, Marubini E, Costa A, Formelli F, Mariani L, Decensi A, Camerini T, Del Turco MR, Di Mauro mg, Muraca mg, Del Vecchio M, Pinto C, D'Aiuto G, Boni C, Campa T, Magni A, Miceli R, Perloff M, Malone WF, Sporn MB: Randomized trial of fenretinide to prevent second breast malignancy in women with early breast cancer. J Natl Cancer Inst 1999, 91:1847-1856.

34. Guerrieri-Gonzaga A, Robertson C, Bonanni B, Serrano D, Cazzaniga M, Mora S, Gulisano M, Johansson H, Intra M, Latronico A, Franchi D, Pelosi G, Johnson K, Decensi A: Preliminary results on safety and activity of a randomized, double-blind, $2 \times 2$ trial of low-dose tamoxifen and fenretinide for breast cancer prevention in premenopausal women. J Clin Oncol 2006, 24:129-135.

35. Decensi A, Robertson C, Guerrieri-Gonzaga A, Serrano D, Cazzaniga M, Mora S, Gulisano M, Johansson H, Galimberti V, Cassano E, Moroni SM, Formelli F, Lien EA, Pelosi G, Johnson KA, Bonanni B: Randomized double-blind $2 \times 2$ trial of low-dose tamoxifen and fenretinide for breast cancer prevention in highrisk premenopausal women. J Clin Oncol 2009, 27:3749-3756

36. Thurlimann B, Keshaviah A, Coates AS, Mouridsen H, Mauriac L, Forbes JF, Paridaens R, Castiglione-Gertsch M, Gelber RD, Rabaglio M, Smith I, Wardley A, Price KN, Goldhirsch A: A comparison of letrozole and tamoxifen in postmenopausal women with early breast cancer. N Engl J Med 2005, 353:2747-2757.

37. Howell A, Cuzick J, Baum M, Buzdar A, Dowsett M, Forbes JF, Hoctin-Boes G, Houghton J, Locker GY,Tobias JS: Results of the ATAC (Arimidex, Tamoxifen, Alone or in Combination) trial after completion of 5 years' adjuvant treatment for breast cancer. Lancet 2005, 365:60-62.

38. Goss PE, Ingle JN, es-Martinez JE, Cheung AM, Chlebowski RT, WactawskiWende J, McTiernan A, Robbins J, Johnson KC, Martin LW, Winquist E, Sarto GE, Garber JE, Fabian CJ, Pujol P, Maunsell E, Farmer P, Gelmon KA, Tu D, Richardson $\mathrm{H}$ : Exemestane for breast-cancer prevention in postmenopausal women. $N$ Engl J Med 2011, 364:2381-2391.

39. Dowsett M, Martin LA, Smith I, Johnston S: Mechanisms of resistance to aromatase inhibitors. J Steroid Biochem Mol Biol 2005, 95:167-172.

40. Dowsett M, Cuzick J, Howell A, Jackson I: Pharmacokinetics of anastrozole and tamoxifen alone, and in combination, during adjuvant endocrine therapy for early breast cancer in postmenopausal women: a sub-protocol of the 'Arimidex and tamoxifen alone or in combination' (ATAC) trial. Br J Cancer 2001, 85:317-324.

41. Bonanni B, Serrano D, Gandini S, Guerrieri-Gonzaga A, Johansson H, Macis D Cazzaniga M, Luini A, Cassano E, Oldani S, Lien EA, Pelosi G, Decensi A: Randomized biomarker trial of anastrozole or low-dose tamoxifen or their combination in subjects with breast intraepithelial neoplasia. Clin Cancer Res 2009, 15:7053-7060

42. Veronesi U, Maisonneuve $\mathrm{P}$, Costa A, Sacchini V, Maltoni C, Robertson C, Rotmensz N, Boyle P: Prevention of breast cancer with tamoxifen: preliminary findings from the Italian randomised trial among hysterectomised women. Italian Tamoxifen Prevention Study. Lancet 1998, 352:93-97

43. Veronesi U, Maisonneuve P, Sacchini V et al:: Tamoxifen for breast cancer among hysterectomised women. Lancet 2002, 359:1122-1124.

44. Decensi A, Gandini S, Serrano D, Cazzaniga M, Pizzamiglio M, Maffini F, Pelosi G, Daldoss C, Omodei U, Johansson H, Macis D, Lazzeroni M, Penotti M, Sironi L, Moroni S, Bianco V, Rondanina G, Gjerde J, Guerrieri-Gonzaga A, Bonanni B: Randomized dose-ranging trial of tamoxifen at low doses in hormone replacement therapy users. J Clin Oncol 2007, 25:4201-4209.

45. Decensi A, Galli A, Veronesi U: HRT opposed to low-dose tamoxifen (HOT study): rationale and design. Recent Results Cancer Res 2003, 163:104-111.

46. Bonanni B, Maisonneuve P, Serrano D, Varricchio C, Cazzaniga M, Lazzeroni M, Rotmensz N, Santillo B, Di Pace R, Latronico A, Belloni C, Rosselli del Turco M, Segnan N, Masullo P, Andreoli C, Monti N, Vella A, D'Aiuto G, Veronesi U, 
Decensi A, for the Italian Hot study group: A phase III prevention trial of low-dose tamoxifen in HRT users: the HOT trial. J Clin Oncol 2012, Suppl:abstr 1500

47. Veronesi U, Viale G, Rotmensz N, Goldhirsch A: Rethinking TNM: breast cancer TNM classification for treatment decision-making and research. Breast 2006, 15:3-8.

48. Guerrieri-Gonzaga A, Botteri E, Rotmensz N, Bassi F, Intra M, Serrano D, Renne G, Luini A, Cazzaniga M, Goldhirsch A, Colleoni M, Viale G, Ivaldi G, Bagnardi V, Lazzeroni M, Decensi A, Veronesi U, Bonanni B: Ductal intraepithelial neoplasia: postsurgical outcome for 1,267 women cared for in one single institution over 10 years. Oncologist 2009, 14:201-212.

49. Guerrieri-Gonzaga A, Botteri E, Lazzeroni M, Rotmensz N, Goldhirsch A, Varricchio C, Serrano D, Cazzaniga M, Bassi F, Luini A, Bagnardi V, Viale G, Mora S, Bollani G, Albertazzi E, Bonanni B, Decensi A: Low-dose tamoxifen in the treatment of breast ductal intraepithelial neoplasia: results of a large observational study. Ann Oncol 2010, 21:949-954.

50. ClinicalTrials.gov: Low-Dose Tamoxifen Citrate in Reducing Breast Cancer Risk in Radiation-Induced Cancer Survivors (LDTam) [http://clinicaltrials. gov/ct2/show/NCT01196936]

51. ClinicalTrials.gov: Trial of Low Dose Tamoxifen in Women With Breast Intraepithelial Neoplasia (TAM-01)

[http://clinicaltrials.gov/ct2/show/NCT01357772]

52. Dunn BK, Greene MH, Kelley JM, Costantino JP, Clifford RJ, Hu Y, Tang G, Kazerouni N, Rosenberg PS, Meerzaman DM, Buetow KH: Novel pathway analysis of genomic polymorphism-cancer risk interaction in the Breast Cancer Prevention Trial. Int J Mol Epidemiol Genet 2010, 1:332-349.

53. Fisher B, Costantino JP, Wickerham DL, Redmond CK, Kavanah M, Cronin WM, Vogel V, Robidoux A, Dimitrov N, Atkins J, Daly M, Wieand S, Tan-Chiu E, Ford L, Wolmark N: Tamoxifen for prevention of breast cancer: report of the National Surgical Adjuvant Breast and Bowel Project P-1 Study. J Natl Cancer Inst 1998, 90:1371-1388.

54. Sitruk-Ware R, Seradour B, Lafaye C: Treatment of benign breast disease by progesterone applied topically. In Percutaneous Absorption of Steroids. Edited by Mauvais-Jarvis P. New York: Academic Press; 1980:219-229.

55. De Boever J, Verheugen C, Van Maele G: Steroid concentrations in serum, glandular breast tissue, and breast cyst fluid of control and P-treated patients. In Endocrinology of Cystic Breast Disease. Edited by Angeli A. New York: Raven Press; 1983:93-99.

56. Mauvais-Jarvis P, Sterkers N, Kuttenn F, Beauvais J: [The treatment of benign pathological conditions of the breasts with progesterone and progestogens. The results according to the type of breast condition (260 case records) (author's transl)]. J Gynecol Obstet Biol Reprod (Paris) 1978, 7:477-484.

57. Mauvais-Jarvis P: Hormonal therapy of benign breast disease. In Current Therapy in Endocrinology. Edited by Krieger DT, Wayne Bardin C. Philadelphia: Mosby Elsevier Health Science; 1983:428-432.

58. Mauvais-Javis P, Baudot N, Castaigne D, Banzet P, Kuttenn F: Trans-4hydroxytamoxifen concentration and metabolism after local percutaneous administration to human breast. Cancer Res 1986, 46:1521-1525.

59. Pujol H, Girault J, Rouanet P, Fournier S, Grenier J, Simony J, Fourtillan JB, Pujol $J \mathrm{~L}$ : Phase I study of percutaneous 4-hydroxy-tamoxifen with analyses of 4-hydroxy-tamoxifen concentrations in breast cancer and normal breast tissue. Cancer Chemother Pharmacol 1995, 36:493-498.

60. Khan SA, Rogers MA, Khurana KK, Meguid MM, Numann PJ: Estrogen receptor expression in benign breast epithelium and breast cancer risk. J Natl Cancer Inst 1998, 90:37-42.

61. Ackerman AB, Kessler G, Gyorfi T, Tsou HC, Gottlieb GJ: Contrary view: the breast is not an organ per se, but a distinctive region of skin and subcutaneous tissue. Am J Dermatopathol 2007, 29:211-218.

62. Povoski SP, Olsen JO, Young DC, Clarke J, Burak WE, Walker MJ, Carson WE, Yee LD, Agnese DM, Pozderac RV, Hall NC, Farrar WB: Prospective randomized clinical trial comparing intradermal, intraparenchymal, and subareolar injection routes for sentinel lymph node mapping and biopsy in breast cancer. Ann Surg Oncol 2006, 13:1412-1421.

63. Wu X, Hawse JR, Subramaniam M, Goetz MP, Ingle JN, Spelsberg TC: The tamoxifen metabolite, endoxifen, is a potent antiestrogen that targets estrogen receptor alpha for degradation in breast cancer cells. Cancer Res 2009, 69:1722-1727.
64. Lee O, Ivancic D, Chatterton RT Jr, Rademaker AW, Khan SA: In vitro human skin permeation of endoxifen: potential for local transdermal therapy. Breast Cancer Targets Ther 2011, 3:61-70.

65. Mansel R, Goyal A, Nestour EL, Masini-Eteve V, O'Connell K: A phase Il trial of Afimoxifene (4-hydroxytamoxifen gel) for cyclical mastalgia in premenopausal women. Breast Cancer Res Treat 2007, 106:389-397.

66. Rouanet P, Linares-Cruz G, Dravet F, Poujol S, Gourgou S, Simony-Lafontaine J, Grenier J, Kramar A, Girault J, Le Nestour E, Maudelonde T: Neoadjuvant percutaneous 4-hydroxytamoxifen decreases breast tumoral cell proliferation: a prospective controlled randomized study comparing three doses of 4-hydroxytamoxifen gel to oral tamoxifen. J Clin Oncol 2005, 23:2980-2987

67. ClinicalTrials.gov: 4-Hydroxytamoxifen or Tamoxifen Citrate in Treating Women With Newly Diagnosed Ductal Breast Carcinoma In Situ [http://clinicaltrials.gov/ct2/show/NCT00952731]

68. Stearns V, Mori T, Jacobs LK, Khouri NF, Gabrielson E, Yoshida T, Kominsky SL, Huso DL, Jeter S, Powers P, Tarpinian K, Brown RJ, Lange JR, Rudek MA, Zhang $Z$, Tsangaris TN, Sukumar S: Preclinical and clinical evaluation of intraductally administered agents in early breast cancer. Sci Trans/ Med 2011, 3:106ra108.

69. Murata S, Kominsky SL, Vali M, Zhang Z, Garrett-Mayer E, Korz D, Huso D, Baker SD, Barber J, Jaffee E, Reilly RT, Sukumar S: Ductal access for prevention and therapy of mammary tumors. Cancer Res 2006, 66:638-645.

70. Flanagan M, Love S, Hwang ES: Status of intraductal therapy for ductal carcinoma in situ. Curr Breast Cancer Rep 2010, 2:75-82.

71. Chlebowski RT, Col N, Winer EP, Collyar DE, Cummings SR, Vogel VG, Burstein HJ, Eisen A, Lipkus I, Pfister DG: American society of clinical oncology technology assessment of pharmacologic interventions for breast cancer risk reduction including tamoxifen, raloxifene, and aromatase inhibition. J Clin Oncol 2002, 20:3328-3343.

72. Visvanathan K, Chlebowski RT, Hurley P, Col NF, Ropka M, Collyar D, Morrow M, Runowicz C, Pritchard KI, Hagerty K, Arun B, Garber J, Vogel VG, Wade JL, Brown P, Cuzick J, Kramer BS, Lippman SM: American society of clinical oncology clinical practice guideline update on the use of pharmacologic interventions including tamoxifen, raloxifene, and aromatase inhibition for breast cancer risk reduction. J Clin Oncol 2009, 27:3235-3258.

73. Tchou J, Hou N, Rademaker A, Jordan VC, Morrow M: Acceptance of tamoxifen chemoprevention by physicians and women at risk. Cancer 2004, 100:1800-1806

74. Waters EA, Cronin KA, Graubard BI, Han PK, Freedman AN: Prevalence of tamoxifen use for breast cancer chemoprevention among U.S. women. Cancer Epidemiol Biomarkers Prev 2010, 19:443-446.

75. Ravdin PM: The lack, need, and opportunities for decision-making and informational tools to educate primary-care physicians and women about breast cancer chemoprevention. Cancer Prev Res (Phila) 2010, 3:686-688.

76. Vogel VG, Costantino JP, Wickerham DL, Cronin WM, Cecchini RS, Atkins JN, Bevers TB, Fehrenbacher L, Pajon ER, Wade JL, III, Robidoux A, Margolese RG, James J, Runowicz CD, Ganz PA, Reis SE, Caskill-Stevens W, Ford LG, Jordan VC, Wolmark N: Update of the National Surgical Adjuvant Breast and Bowel Project Study of Tamoxifen and Raloxifene (STAR) P-2 Trial: Preventing breast cancer. Cancer Prev Res (Phila) 2010, 3:696-706.

77. Cuzick J: IBIS II: a breast cancer prevention trial in postmenopausal women using the aromatase inhibitor anastrozole. Expert Rev Anticancer Ther 2008, 8:1377-1385.

78. Cuzick J, Powles T, Veronesi U, Forbes J, Edwards R, Ashley S, Boyle P: Overview of the main outcomes in breast-cancer prevention trials. Lancet 2003, 361:296-300.

79. Cosman F, Baz-Hecht M, Cushman M, Vardy MD, Cruz JD, Nieves JW, Zion M, Lindsay R: Short-term effects of estrogen, tamoxifen and raloxifene on hemostasis: a randomized-controlled study and review of the literature. Thromb Res 2005, 116:1-13.

80. Breuer B, Wallenstein $\mathrm{S}$, Anderson R: Effect of tamoxifen on bone fractures in older nursing home residents. J Am Geriatr Soc 1998, 46:968-972.

\section{doi:10.1186/bcr3233}

Cite this article as: Lazzeroni $\mathrm{M}$, et al:: Oral low dose and topical tamoxifen for breast cancer prevention: modern approaches for an old drug. Breast Cancer Research 2012, 14:214. 